\title{
Estimation of Heavy Metals in Neem Tree Leaves along Katsina - Dutsinma - Funtua Highway in Katsina State of Nigeria
}

\section{*11LAWAL, A O ${ }^{\text {; }}$ BATAGARAWA, S M; ${ }^{1}$ OYEYINKA, O D; ${ }^{3}$ LAWAL, M O}

\author{
${ }^{1}$ Nuclear Technology Centre, Nigerian Atomic Energy Commission, Sheda, Abuja, Nigeria. \\ ${ }^{2}$ Chemistry Department, Umar Musa Yar' adua University, Katsina, Nigeria. \\ ${ }^{3}$ Biological Science Department, Bayero University Kano, P.M.B. 3011, Kano, Nigeria. \\ *Corresponding author: Email. abdulmojeedlawal@yahoo.com
}

\begin{abstract}
Widespread and growing use of medicinal plants has created public health challenges in terms of quality, safety and effectiveness. Using Atomic Absorption Spectrophotometer (AAS), concentrations of Ni, Zn, $\mathrm{Mn}, \mathrm{Cu}, \mathrm{Cr}$ and $\mathrm{Pb}$, were determined in samples of neem tree (Azadirachta indica) leaves obtained from Katsina, Dutsinma, Kankara and Funtua along Katsina - Dutsinma - Funtua highway in Katsina state of Nigeria. The mean level of the metals in the various locations along the highway varied between $\mathrm{Ni}(1.14 \mathrm{mg} / \mathrm{Kg}$ and $1.92 \mathrm{mg} / \mathrm{Kg}) ; \mathrm{Zn}$ (2.48mg/Kg and 6.08mg/Kg); $\mathrm{Mn}(2.67 \mathrm{mg} / \mathrm{Kg}$ and $4.72 \mathrm{mg} / \mathrm{Kg}) ; \mathrm{Cu}(1.91 \mathrm{mg} / \mathrm{Kg}$ and $2.99 \mathrm{mg} / \mathrm{Kg}) ; \mathrm{Cr}(0.17 \mathrm{mg} / \mathrm{Kg}$ and $0.37 \mathrm{mg} / \mathrm{Kg})$ and $\mathrm{Pb}(0.77 \mathrm{mg} / \mathrm{Kg}$ and $2.25 \mathrm{mg} / \mathrm{Kg})$. Samples from Katsina indicated the highest levels of $\mathrm{Zn}, \mathrm{Ni}$ and $\mathrm{Pb}$ while samples from Funtua indicated the highest levels of $\mathrm{Cu}$ and $\mathrm{Cr}$. However, the levels of all metals obtained from the samples from various locations along the highway were below the WHO/FDA permissible levels of heavy metals in herbal plants. @ JASEM
\end{abstract}

\section{Key Words: Neem tree, Heavy metals, Pollution}

Determination of chemical composition of plants is one of the most frequently used methods of monitoring environmental pollution. Various plants have been used as bioindicators to assess the impact of a pollution source on the vicinity which is due to high metal accumulation of plants (Onder and Dursun, 2006). Uptake of elements into plants can happen via roots from soil and transported to the leaves; also they may be taken up from the air, or by precipitation directly via the leaves (Kord et al., 2010). Kakulu (1993) used Polytrichum junipercum found on the bark of Azadrachta indica to assess heavy metal pollution and confirmed that the concentrations of pollutants in the tree bark correlate with those of the environment. Soil and vegetation pollution have been a serious problem in recent years in Nigeria, especially among the communities living along the major highways. Excessive accumulation of heavy metal in agricultural land through traffic emission may results in soil contamination and elevated heavy metal uptake by crops, and thus affect food quality and safety (Garcia and Millan, 1998). The Nigerian situation is further exacerbated by the reality of increasing large-scale importation of old/fairly used vehicles for use on the Nigerian highways (Alo, 2008). Heavy metals are important group of pollutants. They are non-biodegradable, hence are not readily detoxified and removed by metabolic activities once they are available in the environment. This may subsequently lead to their build up to toxic levels or bioaccumulation in ecosystem. Bioaccumulation of these heavy metals in man, animals and plants result in metal poisoning (Audu and Lawal, 2005). Metals enter the system through the food chain from environmental contamination. Heavy metals are natural constituents of the Earth's crust and are present in varying concentrations in all ecosystems. However, human activity has drastically changed the biogeochemical cycles and natural balances of some of these metals (Hurrel, 1997).

Neem tree (Azadirachta indica) is a tropical evergreen tree native to tropical South East Asia, Africa and other southeast countries. It is a fast growing tree that can survive drought and poor soil and keeps its leaves all year round. It is a tall tree, up to 30 meters high, with leafy spreading branches. Neem tree is a medicinal plant (Heinrich, 2005). In Nigeria, neem extracts have been widely used locally for decades to treat many health problems (Sofowora, 1982). Pure neem leaves and barks have found various applications locally in producing natural medicines and natural herbal cosmetics. Neem leaves are used to treat chickenpox and warts by bathing in water with it or directly applying to the skin in a paste form. In order to increase immunity of the body, neem leaves are made into a tea or powdered to be mixed with water. Tea made from the neem leaves is also taken to reduce fever caused by malaria. The seeds bark and leaves contain compounds with proven antiseptic, antiviral, antipyretic, antiinflammatory, anti-malaria, anti-infertility, anti-ulcer and antifungal uses (Ganguli, 2002). Over the past decade, herbal medicines have been accepted universally, and they have an impact on both world health and international trade. Hence, medicinal plants continue to play an important role in the health 
care system of a large number of the world's population. The herbal products have been classified under 'dietary supplements' and are included with vitamins, amino acids and other products intended to supplement the diet (Rao,2004). Herbal medicine has been recognized by WHO as integral part of primary health system. Primary Health Care (PHC) is the key to the development of a national health policy. It is the first level of contact for the individual, family and the community within the national health care system, bringing health care as close as possible to where people live and work and thus constitutes the first element of a continuing health care process (WHO, 1978a). The major challenge with medicinal plants, such as Neem plant leaves, is that scientifically-based evidence on Traditional Medicine, quality standards and regulations are not being developed at the same pace as the demands for the medicines (Elujoba, 2005).

Consequently, due to increase in environmental pollution across the country (Nigeria), especially along the highways, this study is to estimate the levels $\mathrm{Pb}, \mathrm{Cr}, \mathrm{Zn}, \mathrm{Cu}, \mathrm{Mn}$ and $\mathrm{Ni}$ in neem tree leaves exposed to motor vehicle emissions along Katsina Dutsinma - Funtua highway, in Katsina State of Nigeria, in order to assess the level of accumulation of these metals in the leaves as a measure of environmental pollution as well as the health risks on the part of the consumer.

\section{EXPERIMENTAL}

Analytical reagent grade (Analar) chemical and distilled water were used throughout the work. All glassware and plastic containers were washed with detergent, 20\% nitric acid and then rinsed with tap water and finally with distilled water.

Collection and Preparation of Samples: The neem tree (Azadirachta indica) leaves were collected from Funtua (FT), Kankara (KK), Dutsinma (DM), and Katsina (KT) along Katsina - Dutsinma - Funtua highway in Katsina State of Nigeria. The samples were collected in May 2007 from three different neem trees in each location wrapped in a brown envelope each and labeled accordingly (Egereonu and Onuchukwu, 2000).

In the laboratory, each sample was washed with water and dried in an oven at $70^{\circ} \mathrm{C}$ and they were grounded into powder, sieved and then kept in an air tight screw cap plastic containers ready for digestion (Audu and Lawal, 2005)

Digestion of Samples: A $1.0 \mathrm{~g}$ of the powdered sample was weighed into a conical flask in triplicate. $10 \mathrm{~cm}^{3}$ of the digestion mixture (a mixture of sulphuric acid, perchloric acid and nitric acid in ratio 1: 4: 40 by volume) was added and left to stand overnight. Thereafter, the flask was heated at $70^{\circ} \mathrm{C}$ for about 40 minutes and then, the heat was increased to $120^{\circ} \mathrm{c}$. The mixture turned black after a while and the digestion was complete when the solution became clear with appearance of white fumes (Audu and Lawal, 2005). The digest was diluted with $10 \mathrm{~cm}^{3}$ of water and boiled for 15 minutes. This was then allowed to cool, transferred into $50 \mathrm{~cm}^{3}$ volumetric flasks and diluted to the mark with water. The sample solution was then filtered through a filter paper into a screw capped polyethylene bottle and stored for heavy metal determination using Alpha 4 Atomic Absorption Spectrophotometer with a digital read out system.

\section{RESULTS AND DISCUSSION}

Table 1 shows the mean concentrations of $\mathrm{Ni}, \mathrm{Zn}$, $\mathrm{Mn}, \mathrm{Cu}, \mathrm{Cr}$ and $\mathrm{Pb}$ in the samples of neem tree leaves obtained from various locations along the Katsina Dutsinma - Funtua highway. The magnitude of these metals detected in the samples from different locations along the highway was $\mathrm{Zn}>\mathrm{Mn}>\mathrm{Cu}>\mathrm{Pb}$ $>\mathrm{Ni}>\mathrm{Cr}$ (fig. 1).

Table 1 : Metal Concentrations $(\mathrm{mg} / \mathrm{Kg})$ in the samples of neem tree leaves from different locations along Katsina - Dutsinma - Funtua highway

\begin{tabular}{|l|l|l|l|l|l|l|}
\hline Sample Locations & \multicolumn{7}{|c|}{ Metal Concentration $(\mathrm{mg} / \mathrm{Kg})$} \\
\hline & $\mathrm{Ni}$ & $\mathrm{Zn}$ & $\mathrm{Mn}$ & $\mathrm{Cu}$ & $\mathrm{Cr}$ & $\mathrm{Pb}$ \\
\hline KT & $1.92 \pm 0.87$ & $6.08 \pm 1.23$ & $2.67 \pm 0.62$ & $1.91 \pm 0.41$ & $0.17 \pm 0.005$ & $2.25 \pm 0.67$ \\
\hline DM & $1.14 \pm 0.31$ & $4.95 \pm 0.93$ & $3.33 \pm 0.71$ & $2.60 \pm 0.55$ & $0.23 \pm 0.006$ & $1.16 \pm 0.49$ \\
\hline KK & $1.26 \pm 0.52$ & $2.48 \pm 0.81$ & $4.72 \pm 0.95$ & $2.23 \pm 0.92$ & $0.29 \pm 0.005$ & $0.77 \pm 0.27$ \\
\hline FT & $1.43 \pm 0.36$ & $4.32 \pm 1.11$ & $3.60 \pm 0.87$ & $2.99 \pm 0.77$ & $0.37 \pm 0.008$ & $1.66 \pm 0.35$ \\
\hline
\end{tabular}

Generally, from the result, the mean concentration of $\mathrm{Ni}$ ranged from $1.14 \mathrm{mg} / \mathrm{Kg}$ in $\mathrm{DM}$ to $1.92 \mathrm{mg} / \mathrm{Kg}$ in $\mathrm{KT}$ samples. The mean concentration range of $\mathrm{Zn}$ was $2.48 \mathrm{mg} / \mathrm{Kg}$ to $6.08 \mathrm{mg} / \mathrm{Kg}$ with the highest concentration obtained from KT while the lowest concentration was obtained from KK samples. The mean concentration of $\mathrm{Mn}$ ranged from $2.67 \mathrm{mg} / \mathrm{Kg}$ to $4.72 \mathrm{mg} / \mathrm{Kg}$ with the highest concentration recorded in KK samples and the lowest in KT's. The mean concentration of $\mathrm{Cu}$ ranged from $1.91 \mathrm{mg} / \mathrm{Kg}$ to 
$2.99 \mathrm{mg} / \mathrm{Kg}$ with the highest concentration obtained from FT and the lowest from KT samples. The mean concentration range of $\mathrm{Cr}$ was from $0.17 \mathrm{mg} / \mathrm{Kg}$ in KT samples to $0.37 \mathrm{mg} / \mathrm{Kg}$ in the samples from FT. And the mean concentration of $\mathrm{Pb}$ ranged from $0.77 \mathrm{mg} / \mathrm{Kg}$ in $\mathrm{KK}$ samples to $2.25 \mathrm{mg} / \mathrm{Kg}$ in the samples from KT (Figs. 1).

Generally, samples from KT show highest concentrations of $\mathrm{Zn}, \mathrm{Ni}$, and $\mathrm{Pb}$ while samples from FT show the highest concentrations of $\mathrm{Cu}$ and $\mathrm{Cr}$ (fig. 1) along the highway. High levels of $\mathrm{Pb}$ in $\mathrm{KT}$ and FT samples and high level of Ni in KT samples along the highway could be attributed to high commercial, industrial and automobile activities in these locations compared to other locations along the highway. Furthermore, high levels of $\mathrm{Zn}$ in KT and DM samples, high levels of $\mathrm{Cu}$ in FT and DM samples and high levels of Mn in KK samples (fig. 1) can be attributed to the geological status of these locations along the highway (Lawal and Batagarawa, 2005). However, the levels of all the metals analyzed in the samples of neem tree leaves in this study are below the permissible limits recommended by WHO/FDA in herbal medicine.

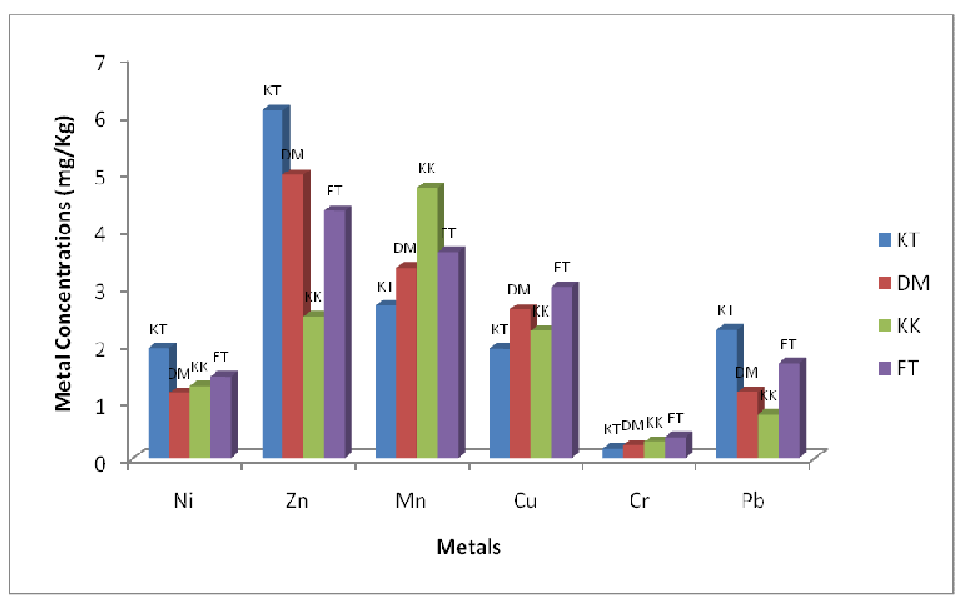

Fig.1: Metal Concentrations in Leaf Samples from Different Locations along the Highway.

Although, it is evident that the concentrations of lead in all the locations in this study are below the permissible level established by CODEX (WHO/FDA) of $10 \mathrm{mg} / \mathrm{Kg}$ in herbal medicine it is still on the high side. This is based on the fact that according to WHO estimates, more than $80 \%$ of people in developing countries depend on traditional medicine for their primary health needs. A health system, based on primary health care was adopted as the means of achieving the goal of health for all by the year 2000. Therefore, by implication, many rural and urban families living along this highway in Nigeria are exposed to a high potential health risks associated with lead metal.

Lead is a prime environmental pollutant and a probable human carcinogen. Exposure to high lead levels can severely damage the brain and kidneys and ultimately cause death. In pregnant women, high levels of exposure to lead may cause miscarriage and high level exposure in men can damage the organs responsible for sperm production (Martin and Griswold, 2009). Lead was the first metal that was demonstrated to have detrimental effect on male fertility (Olayemi, 2010). Analysis of sperm count in lead workers showed a decreased sperm count as well as decreased motility and lifespan of sperm, in direct relation to the level of lead in the blood (Xuezhi et al., 1992). It is also a multiorgan poison which in addition to well known toxic effects depresses immune status, causes damage to the central nervous system, kidney and reproductive system (Alao et al.2010).

Conclusion: The results of this study have indicated the presence of the heavy metals analyzed at varying degrees in all the samples of neem tree leaves from various locations along Katsina - Dutsinma - Funtua highway. Samples from Katsina showed highest contamination by the metals followed by Funtua samples especially with the more hazardous metals like $\mathrm{Pb}$ and $\mathrm{Ni}$. This might be attributed to the geological status of the area under investigation, the ability of plants and their specific parts to accumulate metals and as well as the vehicular emissions along the highway. Even though the levels of all metals analyzed are below the permissible level of heavy metals in herbal plants established by CODEX 
(WHO/FAO) this study further confirms the increased danger of environmental pollutions along our highways due to vehicular emission. However, extended consumption could put the consumers of this valuable medicinal leaves at risk health wise. Therefore, it is hereby recommended that people living along this highway should desist from using leaves of neem trees very close to the highway for herbal purposes.

\section{REFERENCES}

Alao, O; Arojojoye, O; Ogunlaja, O; Famuyiwa, A (2010). Impact assessment of brewery effluent on water quality in Majawe, Ibadan, Southwestern Nigeria. Researcher, 2 (5): 21-28.

Alo, BI (2008). Contribution of Road Transportation to environmental Degradation in Nigeria's Urban Cities, LAMATA Annual National Conference on Public transportation, Lagos, Wednesday $7^{\text {Th }}$ May, 2008.

Audu, AA; Lawal, AO (2005). Variation in Metal Contents of Plants in Vegetable garden sites in Kano Metropolis. Journal of Applied Science and Environmental Management, 10(2): 105-109

Egereonu, UU; Onuchukwu, AI (2000). Assessment of Atmospheric Residual Aerosol from different Satellite Stations II: Heavy Elemental Pollutants. J. Chem. Soc. Nig. Vol.25, 23 .

Elujoba, AA; Odeleye, OM; Ogunyemi, CM (2005).Traditional Medicine Development for Medical and Dental Primary Health Care Delivery System in Africa. Afr. J. Traditional, Complementary and Alternative Medicines. Www.africanethnomedicines.net

Ganguli, S (2002). Neem: A Therapeutic for all Reasons. Current Science, Vol. 82, No. 11, June. pp. 1304.

Garcia, R; Millan, E (1998). Assessment of Cd, $\mathrm{Pb}$ and $\mathrm{Zn}$ contamination in road side soil and grasses from Gipuzkoi (Spain). Chemosphere 37, pp16151625.

Heinrich, M, et al. "Plants as Medicines." in Prance, G. and M. Nesbitt. (2005). The Cultural History of Plants. London: Routledge. 228.
Hurrel, RF (1997). Bioavailability of Zinc. European Journal of Chemistry and Nutrition vol. 57, pp817819.

Kakulu, SE (1993). Biological monitoring of atmospheric trace metal deposition in North- Eastern Nigeria. Environment Monitoring and Assessment, 28:137-143.

Kord, B; Mataji, A; Babaie, S (2010). Pine (Pinus Eldarica Medw.) needles as indicator for heavy metals pollution. Int. J. Environ. Sci. Tech., 7 (1), 7984.

Lawal, AO; Batagarawa, SM (2005). Trace Metal Concentration in some vegetable Plants from Zobe Dam. Isa Kaita Multidisciplinary Journal of Education 2(1) pp30-34.

Martin, S; Grisword, W (2009). Human effects of heavy metals. Eviron. Sci and Tech. Briefs for Citizens. www.engg.ksu.edu/chsr/

Olayemi, FO (2010). A review on some causes of male infertility. African J. of Biotechnology. 9(20), pp2834-2842.

Onder, S; Dursun, S (2006). Air borne heavy metal pollution of Cedrus libani (A. Rich.) in city center of Konya (Turkey). Atmospher. Environ., 40 (6), 11221133.

Rao, KVK; Schwartz, SA; Nair, HK; Aalinkeel, R; Mahajan, S; Chawda, R; Nair, MPN (2004). Plant derived products as a source of cellular growth inhibitory phytochemicals on PC-3M, DU-145 and LNCaP prostate cancer cell lines. Curr. Sci., 87, $1585-1588$

Sofowora, A (1982). Medicinal Plants and African Traditional Medicine in Africa. John Wiley and Sons Ltd. New York.

WHO (1978a). Alma Ata Declaration. Primary Health Care. Health for all series No.1.

WHO Guidelines: Quality Control Methods for Medicinal Plant Materials. Geneva. 3-70 (2004).

Xuezhi J, Youxin L, Yilan W (1992). Studies of lead exposure on reproductive system: A review of work in Chaina. Biomed. Environ. Sci. 5: 266-275. 